\title{
Industrial relations structures in south-east Europe and Turkey: a view from the metalworking industry
}

\section{Introduction}

This study is an academic accompaniment to the EU project Strengthening the social dialogue in south-eastern Europe through CSR instruments. DGB Bildungswerk, the European Metalworkers' Federation (EMF) and the Office of Co-operation Ruhr University Bochum/Industrial Metal Union (GAS) participated in this project; the latter took responsibility for the accompanying research effort. The project ran over the course of one year (June 2006 - July 2007). ${ }^{1}$

The objective of the study was, on the one hand, an improvement in the information basis with respect to economic development in the countries of south-eastern Europe: Bulgaria; Romania; Croatia; Macedonia; ${ }^{2}$ and Turkey (the focus of an earlier article by the same authors, carried in the previous edition of the South-East Review for Labour and Social Affairs). At the same time, another objective was an analysis of industrial relations in these same countries (to which this article turns).

This article therefore considers the situation of the labour and employment conditions, as well as the operational and industry-wide representation structures, in the five countries surveyed in the project. The focus is on the question of the extent to which the process of adjustment of industrial relations in the target countries towards the guidelines and standards of the EU (Art. 19 acquis communautaire) has progressed and, above all, in which form the social dialogue between the social partners has already been legally institutionalised and implemented in practice. It is also the case in this part of the study that, with the support of the project partners from the countries surveyed, the specific elements, structures and problems of the metalworking industry have been registered.

Our comments on industrial relations are based, in addition to the relevant literature, on information obtained from the national experts in our project workshops which were conducted in the five countries surveyed between autumn 2006 and spring 2007. At these workshops, the initially provisional results of a qualitative interview questionnaire which had already been collected prior to the workshops were both discussed with the national experts and deepened. The questionnaire was designed on the basis of the survey criteria of the European Industrial Relations Observatory (EIRO) (Broughton, 2007).

1 This study was produced with the support of the European Commission. It is reproduced here by kind permission. At http://www.emf-fem.org/projects, two more detailed analyses of the economic structures, as well as the industrial relations in the countries surveyed with appendices, are available as a download. In addition, all presentations of the project workshops can be downloaded with content and graphics.

2 For the purposes of this text, the former Yugoslav Republic of Macedonia is referred to as Macedonia. 


\section{Industrial relations}

In the following analyses, the term 'industrial relations' is understood to mean all the standards, procedures and practices, the constellations of people involved and the power structures, as well as the negotiations arenas, of the collective regulation of:

- employment conditions (payment, working time and the start and termination of the contract of employment, as embodying employment relations),

- working conditions (work organisation, conditions of the deployment of labour, skills, industrial safety, as constituting labour relations), as well as

- the formal and informal opportunities for the participation of employees both in the processes of economic production in the company as well as in the formulation of the work and employment conditions within the triad of capital, work and state. (Pries 2001)

Essentially, industrial relations is a question of the development of social civil rights as a consequence of the initial development of civilian, political and ultimately social civil rights, as defined in Article 19 of the acquis communautaire, which are characteristic of the modern industrial and service societies of Europe. That means that, supplementary to the political system of parliamentary democracy, a second system of 'industrial citizenship' has been crystallised following tough social discussions in which social rights are also anchored within the economic sphere of company and entrepreneurship, such as the absolute freedom to associate, the right to collective bargaining and the exclusion of discrimination on grounds of age, sex, religious and political orientation (Marshall, 1963). Thus, a fundamental basis of democratic order is the possibilities for the real participation of employees in the economy and the authentic representation of both employees and employers which arise from it. With the state as a third protagonist, up to now the result has been specifically national systems of industrial relations influenced by a large number of social factors. Social traditions, special cultural features and the development of the balances of power between trade unions and employers, as well as politics, have led to unique models of industrial relations in individual nation states.

However, the economic and political processes of integration in the European Union are leading to a trend towards a dismantling of political barriers on a nation state basis, while the Europeanisation of industrial relations has become an important topic for European trade unions and employer federations. Through the example set by the 'European social model' and the assumption by the member states of the acquis communautaire, the common assets of the EU, a legal framework for action has been created which influences many areas of industrial relations in the nation states. In particular, those states which have been newly admitted to the EU in the course of the expansion to the south-east (Bulgaria and Romania) as of 1 January 2007, as well as those countries (Croatia, Macedonia and Turkey), whose admission is being debated, are faced with a double challenge. On the one hand, they are transformation countries which must adapt either from socialist planned economies or from military dictatorships (Turkey, 1980) to the standards and rules of liberal-capitalist market economies; on the other, these states are challenged to conform with the complex requirements of the EU admission process. The result is that their systems of industrial relations will be confronted not only with new requirements but also with possibilities. 


\section{The structure of industrial relations in Bulgaria}

\section{Social dialogue}

The institutionalisation of social dialogue in Bulgaria was completed on 1 January 2007. The implementation in practice appears, however, to be a process which is proceeding only with difficulty. The varying levels of tripartite co-operation in Bulgaria are regulated by the labour legislation (2001) (Vasileva, 2003). At national level, it operates through the National Council for Tripartite Co-operation (AGB Art. 3a); at sectoral level through Sectoral Councils for Tripartite Co-operation (AGB Art. 3b); and territorially through Regional Councils for Tripartite Co-operation (AGB Art. 3c). Within the last few years, there has been a tendency towards the expansion of tripartite co-operation through the introduction of new mechanisms. At national level, co-operation and consultancy between the social partners are characterised by regular attempts on the part of the Bulgarian government to consolidate the dominant position which it deduces from the legislation. Cooperation at sectoral level and at the regional level is unsatisfactory, according to the social partners, being realised only sporadically.

\section{Social partners}

\section{Trade unions}

Prior to the radical political change, trade union membership in Bulgaria was formally voluntary but it was, however, characterised by an almost one hundred per cent level of organisation in a single trade union organisation, the Central Council of Bulgarian Trade Unions (Daskalova, 2003). With the collapse of the communist regime in 1989, the Bulgarian trade union landscape was pluralised and played a leading role in the transformation process, in particular because there were only relatively under-developed civilian social organisations which would have been capable of dealing with the emerging problems. Currently, there are two trade union umbrella organisations which are recognised as representative at the national level. The Confederation of Independent Trade Unions of Bulgaria (KNSB) originated at the beginning of 1990 out of the old trade union system and consists of 27 trade union federations and 26 individual trade unions, with around 400000 members (as at 2004). The smaller Confederation of Labour 'Support' (KT Podkrepa), with approximately 100000 members, developed in February 1989 out of the trade union movement. It consists of 24 federations and five individual trade unions (FES, 1999).

Both KNSB and KT Podkrepa organise the industrial sectors of metalworking, electrical and mechanical engineering. The relationship between the two umbrella organisations has been characterised by rivalry in the period between 1989 and 1991, which made co-operation at the national level difficult (Detschev, 2003: 255). Today, however, they have a co-operative relationship.

In Bulgaria's metalworking industry, individual trade unions as well as metal trade union federations are organised. They include the trade union 'Metalicy', the national trade union federation 'Metal-Electro', which is a member of KNSB, and the federations 'Mechanical Engineering', 'Metallurgy' and 'Electronics' (CL Podkrepa) from the umbrella organisation KT Podkrepa. ${ }^{3}$

3 No detailed information about further metalworking trade unions in Bulgaria is available. 
The trade union federations have fully-developed structures at sectoral, regional and company levels which enable them to have adequate participation in social dialogue (Ribarova et al, 2001: 4). Within the last few years, the number of members of trade unions in Bulgaria have, however, been declining (Neykov, 2003: 23ff.). According to expert estimates, the degree of trade union organisation amounts to $30 \%$. In addition, there are wide variations in the degree of organisation according to sector - in trade, the level is a mere 1-1.5\% and is estimated to be the lowest in Bulgaria (Gladitscheva, 2004: 17). The decline in membership numbers can be explained by, among other things, the increasing dismantling of industrial sectors, the privatisation of companies, the large number of small and medium-sized enterprises and the growth of the informal sector.

\section{Employer federations}

At present, there are six representative inter-sectoral employer organisations at the national level. The employer organisations already existing before 10 November 1989, the Bulgarian Chamber of Trade and the Bulgarian Chamber of Industry and Commerce, were restructured after the radical change. In addition, new employer organisations have been established, i.e. the Federation of Private Bulgarian Business Leaders Vazrazhdane and the Association of Private Business Companies (1993), which are organisationally weaker than the 'old' employer organisations (Gladitscheva and Detschev, 2003: 8). In 2004, another two employer organisations were recognised as representative at the national level: the Bulgarian Employer Federation; and the Bulgarian Industry Capital Association (BICA) (Zeleva et al, 2005).

The major obstacle to the complete integration of employer organisations into the structures of social dialogue is the result of this strong pluralisation of sectoral employer structures in Bulgaria. Nevertheless, there are still sectors in which no employer representative structures exist. The lack of clearly-defined criteria of representativeness for the sectoral organisations leads to a large number of weak employer federations. These can, simultaneously, be members of more than one nationally-representative employer organisation which, in its turn, makes an assessment of the representativeness of employer organisations at the national level difficult. Many small and medium-sized companies in the informal sector are not organised within employer structures. A weak representation of the interests of an important part of employers in the relevant sectors results from these problems.

\section{Representation of interests at workplace level}

The system of industrial relations in Bulgaria has been characterised since 1 July 2006 by a dual representation of interests. In the course of the transformation process, company trade union organisations which could be founded without limit as regards a minimum number of employees exclusively assumed the function of employee representation. They have strong legal instruments at their disposal, such as participation in tripartite co-operation, wage negotiations, strikes and other legal measures, as a means of representing and protecting the interests and rights of employees in the area of labour and social insurance relationships and living standards (ASM, 2006a: Art. 4). Following an amendment to the Labour Law in 2006, information and consultation rights were assigned to trade union representatives in the event of mass redundancies and company transfers. In order to safeguard, on principle, the right to infor- 
mation and consultation for all employees according to EU norms, the institution of representatives of workers and employees for information and consultation was introduced (ibid, Art. 7a) with the implementation of EU Directive 2002/14/EC in the supplement to and amendment of the Labour Law which came into force on 1 July 2006. This new institution has information and consultation rights in the event of changes in the activities, work organisation and economic situation of a company (Ribarova et al, 2006: 96). The scope of information and consultation can be extended by agreement between the employer and the representatives of workers and employees (ibid: 104).

Both representation of interests structures exist at the company level in parallel, or individually in so far as no trade union representation is available in the company. The representatives of workers and employees for information and consultation are elected, according to the legal regulation, by at least two-thirds of workers in general assembly or a meeting of authorised representatives or, alternatively, this function can be transferred by the general assembly to trade union organisations. Companies with fifty and more workers and employees, as well as organisationally and economically separate units of companies with twenty and more workers and employees, are affected by this regulation (ASM, 2006a: Art 7a). Up to 23 March 2008, this regulation also applies to companies with over 100 employees (Ribarova et al, 2006: 140).

Despite the decision in favour of a dual representation of interests, the competencies of trade union organisations are, according to AGB Art. 7a, more strongly anchored in the law than are those of company representatives of workers and employees. Trade unions are still the most important institutions in Bulgaria which realise information and consultation procedures. In the metalworking industry, the process of information and consultation is handled by the trade unions although in $90 \%$ of companies the process of introducing company representatives of workers and employees has been completed. The introduction of the institution of representatives of workers and employees can, according to the Bulgarian trade unions, only play a positive role in the strengthening of employee representation in those companies in which there is no trade union representation. But even there, there is the danger, as demonstrated by the example of the Bulgarian Liebherr factory, that trade unions are not welcomed by management if there are already representatives of workers and employees in the company.

Practical experience shows that trade union organisations are still the dominant force in employee representation at company level. With respect to the practical implementation of the information and consultation process in Bulgaria, the trade unions report considerable difficulties in, and even violations of, the Labour Law in the form that employers refuse to provide information and consultation, or else make reference to the need for the confidentiality of the information.

\section{Collective bargaining}

With the amendment of and supplement to the Labour Law in March 2001, more favourable conditions were created in Bulgaria for the development of tripartite social dialogue in the form of collective bargaining (Michajlova, 2003: 83ff). Among other things, the amendments cover the content of collective agreements and the standards of wage negotiations. Collective agreements are concluded by representative trade union organisations at the level of companies, sectors and regional administrative 
bodies (ASM, 2006a: Art 51(1)). Company wage agreements can also, however, be concluded by non-representative trade union organisations. In sectoral wage agreements, minimum wages for the sector are defined to be higher than the minimum wage for the country and are specified in detail in company wage agreements according to the category of employees - dependent on training, skills, etc. The object of sectoral wage agreements (BTVs), according to a study by the Institute for Social and Trade Union Research (Michajlova, 2003: 87ff), are also qualitative aspects like training and further education in $38.9 \%$ of BTVs; coupling of remuneration with output in 26.9\%; mechanisms for the adjustment of pay in $23.2 \%$; and the linking of payment with labour productivity in $18.1 \%$.

The Labour and Social Affairs Minister can, in response to a joint demand on the part of the representative social partners, extend the scope of sectoral collective agreements or even single clauses to all companies in the sector or branch. Up to now, however, this option has never been applied in practice.

In recent years, the coverage of collective agreements has steadily declined. According to expert estimates in 2005, coverage was between 30 and 35 per cent. In the period 2001 to 2006,70 sectoral collective agreements as well as wage agreements at the level of national companies and agencies were concluded (information from KNSB, 2006). Despite this trend, the company level remains the dominant level with respect to collective bargaining (Gladitscheva, 2003: 10). From March 2001, approximately 5000 wage agreements have been completed at the company level (information from KNSB, 2006).

The reasons for the deficits in industry-wide sectoral dialogue lie in the structural problems of sectoral employer organisations, as well as in the weak presence of the trade unions, particularly in the private sector.

\section{The structure of industrial relations in Romania}

\section{Social dialogue}

The institutionalisation of tripartite co-operation in Romania started with the foundation of the tripartite Secretariat for the Social Dialogue in 1993 and was continued with the establishment of the Economic and Social Council (ESC) in 1998. In addition, further tripartite structures, which have counselling or decision-making functions, have come into existence (Preda, 2006: 14). At regional and sectoral levels, institutions have also been established in which the social partners co-operate with each other.

The Economic and Social Council is the most important tripartite institution at national level. Its objective is to implement social dialogue between employer organisations, trade unions and the government and to safeguard stability as well as social peace. Co-operation between the government and the social partners is, however, made more difficult by the unsuitable consultation method within the context of the ESC. The trade unions are informed, but they are unable to have an effect on legislation.

Despite the completed process of the institutionalisation of social dialogue, further efforts must be made to improve both the tripartite and the autonomous social dialogue, particularly at branch and sectoral level. The strengthening of the capacities of the social partners with respect to the conclusion of wage agreements takes a priority. 


\section{Social partners}

\section{Trade unions}

Under the communist regime in Romania, the trade unions were a part of the system of the ruling Communist Party, integrated in the General Trade Union Federation (UGSR) (Preda, 2003). At this time, there were several attempts to found free trade unions but these remained, however, unsuccessful. Following the end of the Ceaussescu regime in 1989, the situation came to the dissolution of the communist trade union federation and a strong decentralisation and pluralisation of the trade union landscape in Romania. A wide variety of trade union structures has emerged, particularly at company and sectoral level, which primarily differ from each other ideologically.

In 2003, the new trade union law (No. 54/2003) was passed. According to this law, trade unions are organised according to sectors, occupations or territorial criteria and can combine in federations, confederations or regional associations. Currently, five trade union alliances are recognised as representative social partners at the national level: the Democratic Trade Union Confederation of Romania (CSDR); the National Alliance of Free Trade Unions of Romania (CNSLR Fra ia); the National Trade Union Bloc (BNS); the National Trade Union Association 'Cartel Alfa' (CNS Cartel Alfa); and the National Trade Union Alliance 'Meridian' (CNS Meridian).

Employees from all sectors are represented in the five trade union umbrella organisations (Preda, 2006). The main reason for this lies in the legal regulations with respect to national representativeness, according to which organisations of the social partners must cover at least half the regional administrative bodies and $25 \%$ of national economic sectors. Three of the five national representative trade union confederations are organised in a majority of the regional administrative bodies (BNS, Cartel Alfa and Meridian). The other two (CNSLR Fra ia and CSDR) are represented in all 42 regional administrative bodies.

The five representative trade union federations have different political orientations: CNSLR Fra ia and BNS are social democratic; Cartel Alfa and CSDR are Christian democratic; and Meridian is politically independent (Preda, 2003). Despite their ideological differences, they consistently adopt a common position within the context of the social dialogue. At international level, Romanian trade union confederations are members of ETUC and ITUC (CNSLR Fra ia, BNS, CSDR and Cartel Alfa).

In addition to the umbrella organisations in Romania, there are strong sectoral trade union organisations (e.g. mining, metal processing, education system, trade, agriculture, health service) and several independent trade unions which only partially satisfy the required representativeness criteria. Nevertheless, they can take part in the negotiations and in some cases in agreements with the employer federations and the government.

In the metalworking industry, there are four trade union federations which are organised in different umbrella organisations: ${ }^{4}$ the metal trade union alliance FNS Solidaritatea Metal (SMETAL); the trade union federation of steelworkers (FSS ME-

4 Detailed information about further trade unions in the metalworking industry is not available. 
TAROM); the industry trade union federation (FSLI-METAL); and the metal trade union federation 'Henri Coanda Fra ia'. 5 SMETAL is a member of the national trade union federation Cartel Alfa and represents the sectors of metallurgy, electronics, electrical engineering, mechanical engineering and armaments. The trade union federation of steelworkers, FSS METAROM, is also a member of Cartel Alfa. The industry trade union federation FSLI-METAL belongs to the national trade union bloc, BNS. The metalworking areas of aircraft construction, steel, shipbuilding and armaments are all represented.

There are no official statistics on the degree of organisation of trade unions in Romania. In the 1990s, the level was approximately $80 \%$ but, according to information provided by the Romanian trade unions, it has since declined to about $50 \%$, an indication of the current crisis in which the Romanian trade unions find themselves (Preda, 2003) and which represents the result of several processes. These include a sharp decrease in the number of employed people since 1989, the readiness of employees to give up their trade union membership and the legal framework conditions which make the foundation of trade unions, particularly in small and medium-sized companies, more difficult.

\section{Employer federations}

During the communist regime from 1948 to 1989, no employer federations logically existed in Romania (Ciutacu, 2003b). In the transitional phase to the market economy, the formation of employer organisations proved to be difficult. After the legal framework conditions for employer organisations were adopted only very slowly, many new national employer organisations came into being, with numerous fusions and separations as a result of the restructuring process of companies in the economy. In 2001, law no. 356 was passed by parliament governing the establishment and functioning of employer organisations. According to the law, a total of at least fifteen business leaders is required in order to found an employer organisation.

At the moment, there is a strong trend towards a pluralisation of employer federations at the national level. There are 13 national representative employer federations in Romania which are characterised by different organisational structures (Preda, 2006). ARACO and PNR have existed since 1990, UNPR since 1991, CNIPMMR, CNPR, CONPIROM, CoNPR and UGIR since 1992 and UGIR 1903 since 1994. In 2000, PR was founded, followed by CPISC in 2004. In March 2004 - as the final attempt to unite the employer organisations - two umbrella organisations (ACPR and UPR) were created. The two umbrella organisations represent the interests of employer organisations at national and international level. Only a part of the national employer confederations include federations which are organised on sectoral principles (CNPR, CONPIROM, CoNPR, CPISC, UGIR, UGIR 1903 and CNIPMMR); the rest of the confederations are organised on a regional basis.

5 Further information about membership of an umbrella organisation and the exact sectors represented is not available. 


\section{Representation of interests at workplace level}

The system of industrial relations in Romania is characterised by a monistic structure of the representation of interests. For the foundation of a trade union, at least fifteen employees within a sector are necessary. If no trade union organisation exists within a company and more than twenty persons are employed, they are legally in a position to found employee representation. Trade unions have the right to conduct negotiations with employer representatives to make use of collective resolution instruments, as well as petitions, protests, demonstrations and strikes. Employee representatives are elected by a general assembly of employees on the basis of at least half the votes. Their competencies are restricted in comparison with trade unions and they may not conduct any activities which, according to the labour law, are solely part of the area of competence of trade unions. Such employee representatives are very common but, as a rule, they are bound to the management.

With the law governing the information and consultation of employees (No. 467/ 2006), which came into force on 1 January 2007, the EU directive on information and consultation rights has been implemented in Romania (Ciutacu, 2006). The objective of the law is the creation of a general framework for the information and consultation of employees at company level. All companies which have at least twenty employees are covered. Employers are obliged to inform worker representatives about the economic situation of the company (e.g. employment situation, planned measures for the reduction of jobs) and about decisions with regard to work organisation and employment relationships. For the protection of the employer, obligations to secrecy on the part of employee representatives exist with respect to confidential information, while there is also a release of the employer from the obligation to disclose such information which could seriously harm employees or the interests of the company.

With respect to collective company negotiation processes, trade union agents concentrate particularly on the problems of the extremely low levels of wages. Demands for increases in pay are satisfied only inadequately, despite high increases in productivity and company profits.

\section{Collective bargaining}

According to the law, a collective agreement can be concluded in Romania at company, sectoral and national levels (Mesaros, 2005). In public service, collective agreements are concluded at the administration level or at the level of the local public service, as well as at the departmental level for the subordinate institutions. Collective agreements are binding on all companies with more than 21 employees. Collective agreements can only be concluded by the representative social partners at national, sectoral and company level and are valid for all employees. The terms of a collective wage agreement at a higher level are binding as regards corresponding contracts at subordinate level. The coverage of collective wage agreements amounts to about $60 \%$. The object of sectoral wage agreements are regulations governing working time, holidays, pay, working conditions, industrial safety, vocational training and strikes. In 2005, there were a total of eighteen collective agreements which had become effective (Chivu, 2006). At company level, 8500 company wage agreements have been registered.

In 2003, two major nationwide protests and fewer than ten important sectoral strikes took place, including several in the public service, in public utilities, on the 
railways and in the automobile sector. The three sectors affected by trade union protest measures in 2004 were the metallurgy, transport and mechanical engineering sectors. The main reasons for strikes in Romania are wages and the non-observance of rights defined in collective agreements as well as improvements in working conditions.

\section{The structure of industrial relations in Croatia}

\section{Social dialogue}

The process of the institutionalisation of social dialogue in Croatia has largely been completed. Stable institutional and legal framework conditions had already been established by the end of the 1990s. According to a statement by the European Commission from April 2004, Croatia has also succeeded in adjusting its legal provisions with regard to working time, information and consultation of employees and informing them about individual working conditions to most of the important principles of EU labour law directives. According to the EU Report for 2006, the Croatian Ministry of Economics, Labour and Entrepreneurship initiated a broad consultation with the economic and social partners in June 2006 with the objective of developing a plan of action for the acceptance and/or amendment of the regulations necessary for the implementation of the acquis communautaire (European Commission, 2006a).

Tripartite consultations are taking place at national and regional levels within the framework of the Economic and Social Councils and three different committees of the Croatian Parliament. The government also consults the social partners on the level of the administrative bodies of certain funds and facilities (among others, pension funds, health insurance funds, Media Council, state employment office). (EU Commission statement, 2004)

In this connection, topics for discussion include wages policy, employment policy, health and safety, economic policy and privatisation.

The problems in the area of social dialogue at national level which have been quoted by trade union representatives mainly concern the ways of 'law and proposal circulation' not being known in advance and that it is not mandatory to take into account the opinions of the Economic and Social Council. In addition, the double role of the state in Croatia, as employer and legislator, often has an adverse effect on social dialogue, as does the trade unions frequently not being able to adopt a uniform position.

In addition, the social dialogue is not sufficiently developed at sectoral level in Croatia. There is a lack of well-developed employer and employee structures (see next section).

\section{Social partners}

\section{Trade unions}

Between 1945 and 1990, only one umbrella organisation, the Croatian Trade Union Federation (SSH), existed in Croatia with twenty trade unions (Scherrer, 1997). Trade union membership was based on the principle of automatism and the degree of organisation at that time amounted to $92 \%$. After the system change in 1990, there was a pluralisation of trade unions and a fragmentation of the Croatian trade union scene. 
Many sectoral and industrial unions emerged from the old trade union organisations and individual trade unions became extremely important. A result of the new labour law of 1996/1997 was that the distinction of the trade union scene was also legally promoted. According to this law, a trade union or a federation of trade unions is only recognised and legally responsible if the trade union has at least ten adult members or if the federation of trade unions has at least two trade unions (in total, at least twenty people). In this way, between 1990 and 1999 almost 30 umbrella organisations and about 250 trade unions were registered by the Ministry of Employment.

The large number of trade unions caused structural difficulties for co-operation between the social partners at national level. In consequence, the Act on Determining the Representativeness of Higher-Rank Associations of Trade Unions was passed in the tripartite bodies. The law contains the following criteria which an umbrella organisation must satisfy: registration, of at least 15000 members and at least five trade unions (occupational/sectoral/specialist or company trade unions); financing via trade unions; engagement in at least 11 of the 12 regional administrative bodies; and the signing of three collective agreements at national level.

Currently, there are six representative trade union umbrella organisations: SSSH (Alliance of Independent Trade Unions of Croatia); NHS (Independent Croatian Trade Unions); HUS (Croatian Trade Union Federation); MHSJS (Central Association of Croatian Trade Unions in Public Service); URSH (Federation of Workers' Trade Unions of Croatia); and UNI-CRO (Union Network International - Service Trade Union of Croatia). In 2006, a new umbrella organisation, GLAS.HR, was founded. This organisation unites URSH and UNI-CRO, and seeks to integrate more of the smaller federations listed above, aiming to achieve representativeness next year (Hantke, 2007).

The metalworking industries are represented in SSSH (metal and mechanical engineering) and HUS (metal and shipbuilding). The Metalworking Trade Union of Croatia (SMH) is a member of the umbrella organisation SSSH and the only one in its sector that is a member of the international associations EMF and IMF. ${ }^{6}$ It organises, according to its own information, approximately 21000 metal employees; this corresponds to approximately $48 \%$ of the employees of the companies in which SMH is represented and $26 \%$ of all employees in the metalworking industry (a further 23\% are organised in other trade unions).

The strong pluralisation of trade unions and their lack of ability to adopt a uniform position at national level restrict their possibilities for effectively influencing the social dialogue.

\section{Employer federations}

During the period of socialism, the chamber model applied in Croatia for all employers, with obligatory membership and membership fees directed towards the Croatian Chamber of Commerce (HGK) and the Croatian Chamber of Trade (HOK) (information from SMH). Up to 1994/95, the trade unions signed collective agreements with the chambers and the government. With the foundation in 1994 of the first employer

6 Detailed information about further trade unions in the metalworking industry is not available. 
federation, HUP (Federation of Employers of Croatia), HGK withdrew from the area of collective bargaining. In contrast to the pluralised trade union scene, only three registered employer federations exist, while HUP alone participates in tripartite cooperation. HUP is the strongest and only internationally recognised employer federation. It organises 22 sectoral associations and has three regional offices across the whole of Croatia.

Trade unions demand the passing of a law governing representativeness criteria for employer federations so that they may conclude collective agreements with other sectoral associations. In addition, the lack of transparency of membership of HUP or its member organisations is a target of criticism from the trade union side. The trade union federation SSSH is of the opinion that:

Although it is currently the 'legitimate' employers' representative, without evidence of its representativeness and its unconfirmed role of partner with the trade unions it is presently not an important factor for the promotion of social dialogue concerning company restructuring, wage negotiations and the establishment of the rule of law. (Đurić, 2003)

\section{Representation of interests at workplace level}

In 1996, within the context of the Croatian labour law, a dual system of industrial relations was introduced (Hojnik, 2006). In addition to trade union representation of interests, the labour law provides for the foundation of a workers' council. On the one hand, the role of trade unions in the area of collective bargaining thus continues to be retained while, on the other, workers' councils as institutions of participation may be created within the operational unit. A workers' council (WC) can be founded in companies with at least twenty employees. It consists solely of workers' representatives whose number is dependent upon the number of employees. The process for the establishment of workers' representation can be initiated on the application of a trade union or of at least $10 \%$ of employees. The WC protects and promotes the rights of employees and monitors the application/implementation of the law, collective agreements and company agreements. In addition, it has extensive information, consulting and participation rights. Against the background of the promotion of the rights and interests of employees, the labour law presupposes that the WC co-operates trustingly with all those trade unions whose members are employed by the employer. Co-operation between the trade unions and workers' councils is, however, often adversely affected by rivalries. If no WC is formed in an operational unit, all the rights and duties will be assumed by a trade union intermediary.

The labour law provides for the representation of employee interests also within the context of the Supervisory Board provided that the company has more than 200 employees or where the level of state ownership exceeds $25 \%$. Workers' representatives are elected by the workers' council.

\section{Collective bargaining}

Collective agreements can be concluded in Croatia at national, regional, sectoral and company level (Grgurev, 2002). With the exception of the national wage agreement on the minimum wage, however, there are no general agreements in Croatia which are extended to all workers (Du $\square$ anka Marinkoviæ, 2002: 9). The collective agreement 
regulates the rights and duties of the contracting parties and can also contain regulations regarding the development, content and termination of the employment relationship. In particular, rules governing working time, holiday and wages are made. Collective contractual regulations must not contradict the labour law. Thus, for example, this provides for a maximum working week of 40 hours (50 including overtime). In addition, an obligation to employee training at the place of work is attached; usually, however, this is mentioned only formally in collective agreements and is rarely applied in practice. The minimum wage is not legally set in Croatia but is fixed in a national wage agreement which, by ministerial decision, has validity for all employees (on a generally-binding declaration). In sectoral wage agreements, the area of wagesetting is decentralised in accordance with wage levels, which allows employers either to set the pay level autonomously or to leave this to collective bargaining at the company level. Wages in the metalworking industry are increased nominally from year to year.

In 2005, one hundred collective agreements were applied in Croatia at the national level (information from SMH). About fifteen individual trade unions of SSSH concluded sectoral collective agreements; of this total, five were extended to the entire sector on the decision of the Minister for Economics, Labour and Entrepreneurship. Individual SSSH trade unions signed about six hundred company wage agreements and around $60 \%$ of companies were tied into wage agreements (European Commission, 2004).

In the metalworking industry, SMH has signed a sectoral collective agreement for the shipbuilding industry. Since 1990, SMH has concluded 184 collective agreements at company level. Some companies in the metalworking industry have been declared bankrupt and so 104 of these agreements are still valid today. They have been renewed, as a result of which employees' rights have been improved. Negotiations on collective agreements have been underway since 2006, now for over a year, in the metal and electrical industries. Continuous negotiations are also being conducted on changes to the existing collective agreement in order to achieve increases in wages and qualitative improvements in work and employment conditions.

\section{The structure of industrial relations in Macedonia}

\section{Social dialogue}

The development process of the social dialogue in Macedonia still finds itself in the phase of institutionalisation. An indication of this is the newly-passed labour law of 2005 which contains a number of EU standards, particularly with respect to the information of employees about their individual employment conditions (European Commission, 2005). According to the 2006 report of the European Commission, however, other broader areas, such as the consultation of employees or employee representation in companies with fewer than ten employees, remain to be adapted.

In Macedonia, co-operation takes place at national level within the context of the Economic and Social Council (ESC). The ESC is a tripartite consultative body aimed at strengthening the social dialogue between the social partners and the state. In this connection, the representatives of the social partners have the possibility themselves to discuss economic and social questions relevant to the country and to express their 
opinions as well as make suggestions and recommendations. However, the ESC only has an advisory and not a decision-making function.

The foundations for the establishment of the ESC were laid down in 1996 in an agreement signed by the President, the Federation of Macedonian Trade Unions and the Chamber of Commerce (Casale, 1999). After the anchoring of the ESC in the 2005 Labour Law (Art. 246), this has provided the institutional framework for national social dialogue.

Bipartite social dialogue takes place in the metalworking industry, according to information from the trade union SIER, only at the company level. There, employees are represented by trade unions whose representatives negotiate with management on all questions of internal conflict (see Representation of interests at workplace level, below). At sectoral level, dialogue with employers is not possible as the latter are not yet organised (see Employer federations, below).

\section{Social partners}

\section{Trade unions}

Trade union development in Macedonia after 1990/1991 is characterised by the establishment of sectoral trade unions which consist of relatively independent company trade unions. Company trade unions organise themselves according to their articles of incorporation and have a strong position within the sectoral trade unions (FES, 2004). The representation of interests mainly related to the company and the right to rate completion of an employment contract, as well as the system of financing (member contributions remain, as a rule, within the business), aggravate the construction of strong primary trade union structures.

Article 212 of the 2005 Labour Law defines clear criteria for the representativeness of trade unions as regards the promotion of mergers between trade unions and their active participation in social dialogue. At national and sectoral level, trade unions are regarded as representative if they represent at least $33 \%$ of employees in a sector. This applies in the same way to trade unions at the company level. The representativeness criterion is also fulfilled if a trade union is a member of a representative trade union association at a higher organisational level.

The largest trade umbrella organisation in Macedonia is currently the Federation of Trade Unions of Macedonia (SSM), which has eighteen sectoral trade unions. It was founded in 1989 as the successor organisation to the old centralist Yugoslav trade union federation. Another three national umbrella organisations exist in parallel: the Alliance of Free Trade Unions of Macedonia (KSS), a split-off from SSM since 2005 focused on the representation of public service employees; the Alliance of Trade Union Associations of Macedonia (KSOM), which has united two sectoral trade unions in the transport and engineering industries since 2004; and the Union of Independent and Free Trade Unions (UNASM), which probably exists only on paper as its members are not officially registered and the individual sectoral trade unions have not concluded any wage agreements since the foundation of the Union in 1991 (Hantke, 2007).

The trade union Industry, Energy and Mining of Macedonia (SIER), the only trade union satisfying the representativeness criteria at national level, organises and represents employees in the metalworking industry. It is represented in the areas of the ex- 
traction of iron ore and minerals; the production of steel and non-ferrous metals; metal processing; mechanical engineering; the production of electrical equipment; the automobile and supplier industries; and in the non-metal areas of energy and chemicals. In 2007, the trade union has approximately 17000 members, of whom 12000 are in the metalworking industry. SIER is a member of the umbrella organisation SSM.

\section{Employer federations}

At present, the development of employer federations in Macedonia is proceeding very slowly in comparison with that of trade unions. Before the amendment to the Labour Law in 2005, mandatory membership for all employers of the Chamber of Commerce of Macedonia, which existed as the only employer organisation and had sectoral structures, allowed this organisation to dominate at the national level. The Labour Law passed in 2005 improved the legal bases for employer organisations through its definition of the right to the free foundation of employer federations, a definition of clear criteria for representativeness and the abolition of the automatic representation of the chambers of commerce within the ESC (European Commission, 2005). Despite this improved legal basis, only the Association of Employers of the Republic of Macedonia (CERM) exists; this functions as an umbrella association for employer organisations although it does not have any sectoral or regional structures.

Currently, employers in the metalworking industry are still not organised. The relevant companies have, since 2005, been assigned within the Chamber of Commerce to the two associations 'steel and non-ferrous metallurgy' or 'metal and electrical industry' but this has not, up to now, led to the foundation of employer organisations at sectoral level. The lack of interest of employers in organising themselves represents a structural obstacle to the development of social dialogue at sectoral level and is contrary to the negotiation of sectoral wage agreements.

\section{Representation of interests at workplace level}

Employee representation at workplace level in Macedonia is handled by the trade unions. According to Article 199 of the 2005 Labour Law, the trade unions alone decide on the form and manner in which they conduct representation as regards employers. Within a company, they can propose or elect one or several trade union representatives (the trade union committee), who has/have the right to represent and to protect the interests and rights of trade union members in the company as regards the employer. The time period and the individual details of the work of the trade union committee are fixed in the collective agreement. The trade union is obliged to inform the employer of the nomination of the trade union representative(s). For its part, the employer is obliged towards the trade union and its representative(s) to make possible the timely and successful execution of their rights and to guarantee access to important information. The representative trade unions have the right to conclude collective agreements and to conduct strikes.

The sectoral trade union SIER is represented in all the surveyed companies in the metalworking industry and organises, according to its own information, approximately $90 \%$ of employees. Despite the legal regulations, trade union representatives in the metalworking industry complain of the lack of respect of employers - particularly in private companies - for trade union activities and that, in some cases, they 
even try to hinder them. A large number of companies have not concluded any wage agreements or have not renewed old ones. In individual cases, the concluded wage agreement is not observed (e.g. Mittal Steel CRM).

\section{Collective bargaining}

Collective agreements can be concluded in Macedonia at national, sectoral and company level by representative trade unions and employer federations (Labour Law 2005, Art. 203). If the trade unions or employer federations cannot satisfy the criteria of representativeness according to the labour law, they have the right to reach an agreement as a coalition. The collective agreement at national and sectoral level applies directly to all parties concluding it. The company wage agreement applies to all employees, i.e. also to non-members of the union in the company (Art. 208 (3)). The object of all signed wage agreements are wages and salaries, working time, breaks and leave regulations, working conditions, contracts of employment, periods of notice, disciplinary measures and regulations governing the activities of trade unions in the company as well as strike regulations. The term of collective agreements is legally regulated and is for a two-year period.

The national wage agreement for the private sector was signed in June 2006 by the umbrella organisations of the trade unions, SSM, and of the employers, CERM, while the wage agreement for the public sector remained unsigned (European Commission, 2006). These agreements reached at national level are regarded as setting framework conditions for negotiations at company level in view of the lack of wage agreements in many sectors. For 2005, a total of 30 sectoral wage agreements were recorded which, however, are not systematically observed (European Commission, 2005). Statistics about the number of company wage agreements do not exist at present; however, the trade union SIER reports that it has concluded collective agreements in over half the companies in which it is represented.

Problems during collective bargaining arise not only due to the previously-mentioned absence of organised protagonists at sectoral level but also as a result of the steady weakening of trade union structures arising from the declining degree of organisation $(45 \%)$. In addition, the representatives of trade unions are not, in their own opinion, adequately trained and experienced enough for negotiations. The framework conditions for work and employment conditions are fixed legally or in collective agreements at national level, but the precise level of wages, for example, is negotiated at company level. In this connection, wage levels depend very strongly on the solvency of the company and the negotiating strength of workers' representatives. In the metalworking industry between 2003 and 2006, an increase of 28\% in the gross wage was achieved. The problem of the irregular payment of wages, however, continues to exist. Trade union representatives also have to fight in the area of working time for the implementation of legal or collectively agreed regulations.

\section{The structure of industrial relations in Turkey}

\section{Social dialogue}

The Economic and Social Council has already been offering the possibility of the tripartite co-operation of representatives of government, employers and trade unions since 1995. Nevertheless, the social dialogue proves to be very difficult in Turkey. 
One reason for this lies in the Turkish legislation. Thus, at sectoral level, the social dialogue is still not legally institutionalised. Furthermore, the legal licensing restrictions and the high demands made as regards the representativeness of the trade unions (see Trade unions, below) proves to be a problem for the social partners. In addition, the informal sector is particularly marked in Turkey. Employees who are active in that area are not officially registered and, therefore, cannot be represented by the trade unions. If the structures of industrial relations are not extended to the informal sector, the trade unions will continue to represent only a minority of the actual number of people employed in Turkey. In addition to this institutionally weakened position, trade unions also have to battle in their work with the restriction of their rights. The EU Progress Report 2006 points out that there are still considerable deficits with respect to trade union freedom (freedom to strike, freedom to form coalitions). The fundamental problem, however, is not the adoption of the laws but, rather, their implementation. The trade unions see themselves in this respect as not fully capable of action.

This problem undoubtedly also exists in the metalworking industry. The trade unions see themselves as confronted by superior employers or employer associations. According to their own information, there is no possibility of bipartite social dialogue; contact with employers takes place only during wage negotiations.

\section{Social partners}

\section{Trade unions}

The trade union law of 1947 permits and regulates the foundation of trade unions. Currently, three umbrella organisations exist in the private sector in Turkey and three in the public service sector. In the private sector is the Federation of Turkish Trade Unions (Türk-Is), the largest trade union federation with approximately 2.1 million members and 35 member trade unions. The Federation of Revolutionary Trade Unions (DISK) has approximately 400000 members and 21 member trade unions, while the Islamic-oriented Trade Union Federation (HAK-Is) has approximately 350000 members and nine member trade unions. The trade union umbrella organisations in the public service are Kesk (Federation of Employees in Public Service); Memur-Sen (Alliance of Civil Servant Trade Unions); and Türkiye Kamu-Sen (Alliance of Turkish Civil Servants). The trade union federations in public service were only made possible with the constitutional amendment of 1995, after which numerous civil service trade unions have been founded which, however, have no freedom to strike and are not capable of negotiating pay deals.

The legal bases for the activities of trade unions in the private sector were established in the trade union law under the military dictatorship of 1983. Under its terms, trade unions could organise themselves according to the principle of industry association (GewG No. 2821). The second law (TSAG No. 2822), governing wage agreements, strikes and lockouts, contains detailed regulations governing the conclusion and term of wage agreements, the responsibilities of the trade unions with regard to wage agreements, the process of wage negotiations and the legal arbitration procedure. In order to be able to sign a company wage agreement, the trade union must represent at least $51 \%$ of the employees of the company in question or $10 \%$ of the employees of the sector concerned. In addition, employees must allow themselves even 
today to be registered by a public notary if they want to organise themselves in a trade union. The same applies when leaving a trade union.

There are three trade unions capable of negotiating wage agreements in the metalworking industry. They may only operate in the metal and electrical sector, including workshops, and may not organise themselves in other sectors. Birlesik Metal Is is active in all areas (basic metal production, metal processing and mechanical and electrical engineering, as well as automotive (parts) manufacturing, mainly in the private sector, and organises itself independently of political parties. The trade union is a member of the umbrella organisation DISK. The second metal trade union, Celik-Is, is represented in the former state steelworks and is relatively unimportant in the private sector. The trade union which has close government ties is a member of the proIslamist umbrella organisation HAK-Is. The trade union Türk Metal, in contrast, is supported by the employer federation MESS. It is represented in the important large companies of the metalworking industry. Türk Metal is also organised in a smaller number of state-owned companies and is a member of the umbrella organisation Türk-Is. Employees in the shipbuilding industry in Turkey are organised separately in the sectoral trade union Limter-Is.

\section{Employer federations}

The employer federations were also founded in accordance with the laws of 1947. The only umbrella organisation for employer federations in Turkey is TISK. It was founded in 1962 and originated from the merger of the Union of Istanbul Employer Federations and other employer federations. It supported the military intervention of 1980 and contributed to the creation of the trade union laws of 1983. Currently, TISK has 22 member associations. They are represented in the ILO and are members of the International Federation of Employers (IOE) and of the Union of Associations of Industry and Employers (UNICE).

In addition, there are approximately 34 independent employer federations which are organised in different industrial sectors and do not belong to TISK. They represent mainly the interests of small- and medium-sized companies.

In Turkey, only one metalworking employers' federation exists - MESS. It is a member of the employer umbrella organisation TISK and the Turkish Industrialists Association TÜSIAD.

\section{Representation of interests at workplace level}

The representation of interests at workplace level in Turkey is regulated via trade union representatives in a monistic system. There are further forms of the representation of interests which, however, are not generally applied. They include the workers committee, the establishment of which has once again been possible with the consent of the employer since 1990. In several companies, they work together with the trade unions; in others, they avoid contact with them. Workers committees gained in importance in the 1970s with the increasingly militant labour movement but, after 1980, their influence declined sharply with the establishment of the military dictatorship. They are no longer to be found in practically any company.

In order to mediate in disputes between employees and employers and preserve mutual interests, there are also committees at workplace level on which sit representatives of employees and employers. The establishment of such committees is not oblig- 
atory. It has become more difficult, especially since 1990, to demand the establishment of committees under collective bargaining law. At national level today, it is, above all, the sectoral trade unions and, at workplace level, the trade union representatives who campaign for the rights of employees.

The foundation of organs for the representation of interests at workplace level is not legally stipulated. This arrangement can, however, be implemented via the wage agreement but this proves to be difficult and is to be found only in a few companies. Trade unions organised at company level function as an interface between trade unions and employees on the one hand and employers on the other. Trade union representatives in the company are appointed as a right by the trade union. Some trade unions, however, allow their representatives to be elected by the members of the company and to appoint them in that way. As a rule, the duration of their term of office is two years since wage agreements also predominantly have a two-year term and trade union representatives are appointed in the same rotation.

The task of trade union representatives lies in resolving problems at the workplace and positioning themselves as a link between company and trade union. There is no effective protection against their dismissal so this task can only be conducted under difficult conditions. The labour law provides that the employer can only discontinue the employment relationship for a 'justifiable cause'. This 'justifiable cause', however, is based on a subjective evaluation.

A striking feature of the system of the representation of interests at workplace level in Turkey is the lack of a joint body of representatives of the various umbrella organisations and trade unions. In addition, there is a lack of co-determination mechanisms within the companies. There are no information and consultation rights for employees in Turkey, while there is also no legal framework for the regulation of employee participation. Company representatives must give employees and trade union representatives information neither about the development of company finances, the order situation, etc., nor about the future planning of the company.

\section{Collective bargaining}

According to the law, differentiation is made between three kinds of wage agreement in Turkey which are negotiated and signed by the contracting parties - trade union and employer federation or individual employer:

1. operational unit wage agreement: applies only to a single operational unit

2. company wage agreement: applies to all employees in a sector who are working in different operational units for the same employer, if at least $51 \%$ of the employees of the entire company are organised within the union

3. group wage agreement: applies if the same trade union and the same employer federation are authorised to negotiate wages for several operational units in a sector.

There are no wage agreements which are obligatory for an entire sector.

Wage agreements apply for at least one year and for a maximum of three. The trade union Birlesik Metal Is conducts wage negotiations for those companies in the metalworking industry in which it is organised every second year. Currently, a wage agreement exists which runs from 2006 to 2008. Under pressure from the metal employers' federation MESS, and with the consent of the trade union Türk Metal, it has been collectively agreed that salaried employees cannot organise themselves in a un- 
ion and thus the wage agreements apply only to wage-earning employees. Nevertheless, employers currently grant salaried employees the same conditions. In general, non-organised employees can take advantage of the collectively-agreed wage rates on payment of a solidarity fee.

In terms of content, the wage agreement regulations are broken down into: 'General regulations', 'Wage increases and other financial benefits', 'Regulations governing working hours and leave duration', 'Payments which the employer must make', 'Protection against dismissal' and 'Trade union rights in the companies'. Weekly working hours are regulated, for example, for the metalworking industry as for all other sectors in the wage agreement, at 45 hours. Wages are based on a national minimum wage which, however, in the opinion of the trade unions, is inadequate and incapable of covering the cost of living. There has not been any increase in pay in the metalworking industry in recent years.

The rigid legal regulations for trade unions, in order to conclude wage agreements, have the consequence that only very few operational wage agreements are signed. Thus, the majority of Turkish employees are not protected by wage agreements.

\section{Conclusion and outlook}

With respect to industrial relations, this is a matter of establishing a system of social civil rights in industry, as defined in part within Article 19 of the acquis communautaire of the European Union. One result of this study is that the actual implementation of the regulations of the acquis communautaire is proceeding very differently in the surveyed European states. An essential factor for success is the genuine participation of employees at the level of the workplace and enterprise as a prerequisite for the development of social dialogue. The freedom to form coalitions or trade unions can be considered as essential for the development of work and employment conditions. A further decisive role in the introduction and arrangement of the social dialogue at the operational level is hereby played by the implementation of information and consultation bodies in all European companies with more than twenty employees (2002), which has already happened in the most recent EU member states.

It remains to be said that the formal institutionalisation of the social dialogue has been concluded in Bulgaria, Romania and Croatia although implementation in practice represents a social process which is slow and, in some cases, politically difficult. The pluralisation of trade union organisations is limiting the effectiveness of the social dialogue, however, in both Croatia and Romania. In Macedonia and Turkey, in contrast, the institutionalisation of the social dialogue is not yet particularly advanced. In Turkey above all, the lack of, or the simply not observed, labour and trade union legislation is proving to be a problem. The main problem for the social dialogue in Macedonia is the lack of organisation of employers, so that the co-operation of the social partners is not ensured.

Considered in general, the major deficits and suggestions for the strengthening of social dialogue in the surveyed countries can be summarised as follows: in addition to the frequent lack of representative employer structures, the trade unions are not always capable of asserting themselves as a result of their lack of roots at the workplace level. They must develop their representativeness and their expertise through an improved degree of organisation, co-operation, information and training because, ulti- 
mately, genuine participation of employees at the operational level and the trade union organisations which are based upon that provide the real foundations for the development of social dialogue. They have been unable to develop their social cohesion up to now and their impact in the respective societies has remained limited as, after the company level, the sectoral social dialogue in individual sectors in the countries of south-eastern Europe and Turkey is only at the start of its development. In future, cross-border trade union networks at the level of multinational companies could provide support here. Nevertheless, a serious hindrance arises not least due to structural problems on the labour markets, compared with the EU average, as well as in the relatively low share of employees subject to social insurance and the high share of informal sector employees who thereby remain excluded from the regulations and practices of industrial relations. The reduction of precarious and informal employment, and the consistent integration of these employee groups, represents one of the future challenges for social dialogue in the surveyed countries.

\section{References $^{7}$}

Arbeits- und Sozialministerium Bulgarien (ASM) (2006a): Arbeitsgesetzbuch http://www.mlsp.government.bg/bg/law/law/KODEKS\%20NA\%20TRUDA.rtf

Auswärtiges Amt der Bundesrepublik Deutschland (AA) (Ed.) (2007): Bericht der Botschaft Ankara vom 27.2.2007 zur wirtschaftlichen Entwicklung und zu wichtigen Messen in der Türkei http://www.auswaertiges-amt.de/diplo/de/Laender/ Wirtschaftsberichte/Tuerkei-Ankara070227.pdf

Baydar, Oya (1999): Gewerkschaften in der Türkei. Historische Entwicklung, Organisationsstrukturen und rechtliche Rahmenbedingungen FES: Istanbul.

Broughton, Andrea (2007): Comparative overview of industrial relations in 2005, in: Eurofound (Ed.)

http://www.eurofound.europa.eu/eiro/2006/01/feature/tn0601103f.html

Casale, Giuseppe (1999): Social Dialogue in Central and Eastern Europe in: ILO (Ed.)

http://www.ilo.org/public/english/region/eurpro/budapest/download/ social_dialogue_cee.pdf

Centre for the Study of Democracy (CSD) (Ed.) (2004): The Hidden Economy in Bulgaria www.csd.bg

Chivu, Luminia (2006a): EIRO 2005 Annual Review for Romania in: Eurofound (Ed.) http://www.eurofound.europa.eu/eiro/2006/01/feature/ro0601102f.html

Chivu, Lumini a (2006b): Employer organisations move towards greater cohesion in: Eurofound (Ed.) http://www.eurofound.europa.eu/eiro/2006/09/articles/ro0609039i.html

Ciutacu, Constantin (2006): New regulations on information and consultation of employees in: Eurofound (Ed.)

http://www.eurofound.europa.eu/eiro/2006/08/articles/ro0608049i.html

7 It is a selection of all the literature and sources used in the report that is cited here. 
Commission of the European Communities (2006): Commission Staff Working Document. The Former Yugoslav Republic of Macedonia 2006 Progress Report http://ec.europa.eu/enlargement/pdf/key_documents/2006/nov/ fyrom_sec_1387_en.pdf

DGB Bildungswerk/IG Metall-Vorstand/Gemeinsame Arbeitsstelle RUB/IGM (Ed.) (2005): Länderprofil: Türkei. Tradition und Wandel.

Đurić, Dragan (2003): Social Dialogue, Tripartism and Social Partnership Development in South-East European Countries, Including Recommendations for Serbia and Montenegro in: Central European University (Ed.) http://pdc.ceu.hu/archive/ $\underline{00001829 / 01 / D j u r i c . p d f}$

Deutsches Institut für Wirtschaftsforschung (DIW Berlin) (Ed.) (2004):

Wochenbericht http://www.diw.de/deutsch/produkte/publikationen/ wochenberichte/docs/04-14.pdf

Europäische Kommission (2006a): Arbeitsdokument der Kommissionsdienststellen. Kroatien. Fortschrittsbericht 2006

http://ec.europa.eu/enlargement/pdf/key_documents/2006/nov/hr_sec_1385_de.pdf

Europäische Kommission (2006b): Arbeitspapier der Kommissionsdienststellen. Rumänien. Monitoring-Bericht von Mai 2006 http://www.pedz.uni-mannheim.del daten/edz-k/gde/06/monitoring report ro de.pdf

Europäische Kommission (2006c): Arbeitsdokument der Kommissionsdienststellen. Türkei. Fortschrittsbericht 2006

http://ec.europa.eu/enlargement/pdf/key_documents/2006/nov/tr_sec_1390_de.pdf

European Bank of Reconstruction and Development (EBRD): http://www.ebrd.com/

European Industrial Relations Observatory (EIRO):

http://www.eurofound.europa.eu/eiro/

Federation of International Trade Associations (FITA): http://www.fita.org/

FES (2004): Gewerkschaftskooperation mit Osteuropa Bonn (Electronic ed.) in: FES library (Ed.) http://library.fes.de/pdf-files/netzquelle/c95-00020.pdf

FES (Ed.) (1999): Gewerkschaften und Arbeitsmarkt in Südosteuropa: Ungarn, Slowenien, Kroatien, Bosnien-Hercegovina, Bundesrepublik Jugoslawien, Bulgarien, Rumänien, Albanien, Mazedonien Bonn.

Gladitscheva, R. (2004): 'Das gegenwärtige bulgarische Modell der industriellen Beziehungen und die westeuropäischen Modelle. Vergleichsanalyse' in: Gladitscheva, et al. (Ed.): Bulgarien vor dem EU-Beitritt. Tripartite Zusammenarbeit und die Entwicklung der Arbeitsbeziehungen. Vergleichsmodelle und Analyse Institut für regionale und internationale Forschung: Sofia.

Gladitscheva, R and Detschev (2003): Die Arbeitgeberorganisationen in Bulgarien und ihre Teilnahme am Sozialdialog auf Branchen- und Setoralebene Institut für regionale und internationale Forschung: Sofia.

HBS/ETUI (Ed.) (2005): South-East Europe Review for Labour and Social Affairs $8(1)$. 
Hantke, Frank (2007): Süd-Ost-Europa: Übersicht über die Organisationen der Sozialpartner in der Region in: FES (Ed.)

http://www.fes.de/wiso/pdf/abp/2007/hantke_uebersicht-sozialpartner.pdf

Hojnik, Janja (2006): Croatia. The employee representation system in Croatia in: SEEurope (Ed.)

http://www.seeurope-network.org/homepages/seeurope/file_uploads/ croatiacountryreport.pdf

Hristov and Serbesova (2001): Kommentar über die Änderungen und Ergänzungen im Arbeitsgesetzbuchs KNSB/FES: Sofia.

Konföderation der Unabhängigen Gewerkschaften in Bulgarien (KNSB): http://www.knsb-bg.org/eng/enindex.htm

Marshall, T. H (1963): 'Citizenship and Social Class' in: Sociology at the Crossroads and Other Essays London, pp. 67-128.

Mesaros, Serghei (2005): The Evolving Structure of Collective Bargaining in Europe 1990-2004. National Report. Romania Project Report 'The Evolving of Collective Bargaining', European Commission/University of Florence.

Michajlova (2003): 'Soziale Partnerschaft und sozialer Dialog in den zentral- und osteuropäischen Beitrittsländern. Vergleichsanalyse' in: Gladitscheva et al. (Ed.): Bulgarien vor dem EU-Beitritt. Tripartite Zusammenarbeit und die Entwicklung der Arbeitsbeziehungen. Vergleichsmodelle und Analyse Institut für regionale und internationale Forschung: Sofia.

National Institute of Statistics of Romania (NIS):http://www.insse.ro/cms/rw/pages/ index.en.do

National Statistical Institute of Bulgaria (NSI): http://www.nsi.bg/index e.htm

Neykov, Ivan (2006): EIRO 2005 Annual Review in: Eurofound (Ed.) http://eurofound.europa.eu/eiro/2006/01/feature/bg0601103f.html

Platzer, Hans-Wolfgang (2005): Nationale Modelle der Arbeitsbeziehungen in den neuen EU-Mitgliedsländern. 6. Internationale Konferenz der Otto Brenner Stiftung vom 25. bis 27. April in Wroclaw in: OBS (Ed.)

http://www.otto-brenner-stiftung.de/fix/docs/files/platzer 050426.pdf

Preda, Diana (2006): Capacity building for social dialogue in Romania in: Eurofound (Ed.) http://www.eurofound.europa.eu/pubdocs/2006/5110/en/1/ef065110en.pdf

Pries, Ludger (2001): 'Industrielle Beziehungen im globalen Wandel' in: Abel and Sperling (Ed.): Umbrüche und Kontinuitäten. Perspektiven nationaler und internationaler Arbeitsbeziehungen. Walther Müller-Jentsch zum 65. Geburtstag München und Mering: 295-313.

Republic of Croatia - Central Bureau of Statistics (CROSTAT): http://www.dzs.hr/ default e.htm

Republic of Macedonia - State Statistical Office (SSO): http://www.stat.gov.mk/english/glavna eng.asp

Ribarova, Stantscheva and Hristov (2006): Kommentar. Gesetz über die Änderungen und Ergänzungen des Arbeitsgesetzbuchs. Gesetz über die Information und Kon- 
sultation der Arbeiter und Angestellten in multinationalen Unternehmen, Gruppen von Unternehmen und Europäischen Gesellschaften KNSB/FES: Sofia.

Sengenberger, Werner (2006): Employment and Development in South-East Europe in the Context of Economic Globalization. A background paper prepared for the Sub-Regional European Conference on Globalization and Employment, Istanbul, 11 and 12 September 2006, in: ILO (Ed.)

http://www.ilo.org/public/english/region/eurpro/geneva/download/events/istanbul/background.pdf

Skarby, Elina (2006): Representativeness of branch employer organisations under debate in: Eurofound (Ed.)

http://www.eurofound.europa.eu/eiro/2006/10/articles/bg0610039i.html

Statistical Office of the European Communities (EUROSTAT):

http://epp.eurostat.ec.europa.eu/portal/page? pageid=1090,30070682,1090

$\underline{33076576 \& \text { dad=portal\& schema=PORTAL }}$

Statistisches Bundesamt Deutschland (DeSTATIS): http://www.destatis.de/

Turkish Statistical Institute (TURKSTAT): http://www.turkstat.gov.tr/

Wiener Institut für Internationale Wirtschaftsvergleiche (WIIW) (2006a): wiiw Database on Foreign Direct Investment in Central, East and South-East Europe Vienna.

Wiener Institut für Internationale Wirtschaftsvergleiche (WIIW) (2006b): wiiw Industrial Database Eastern Europe Vienna. 


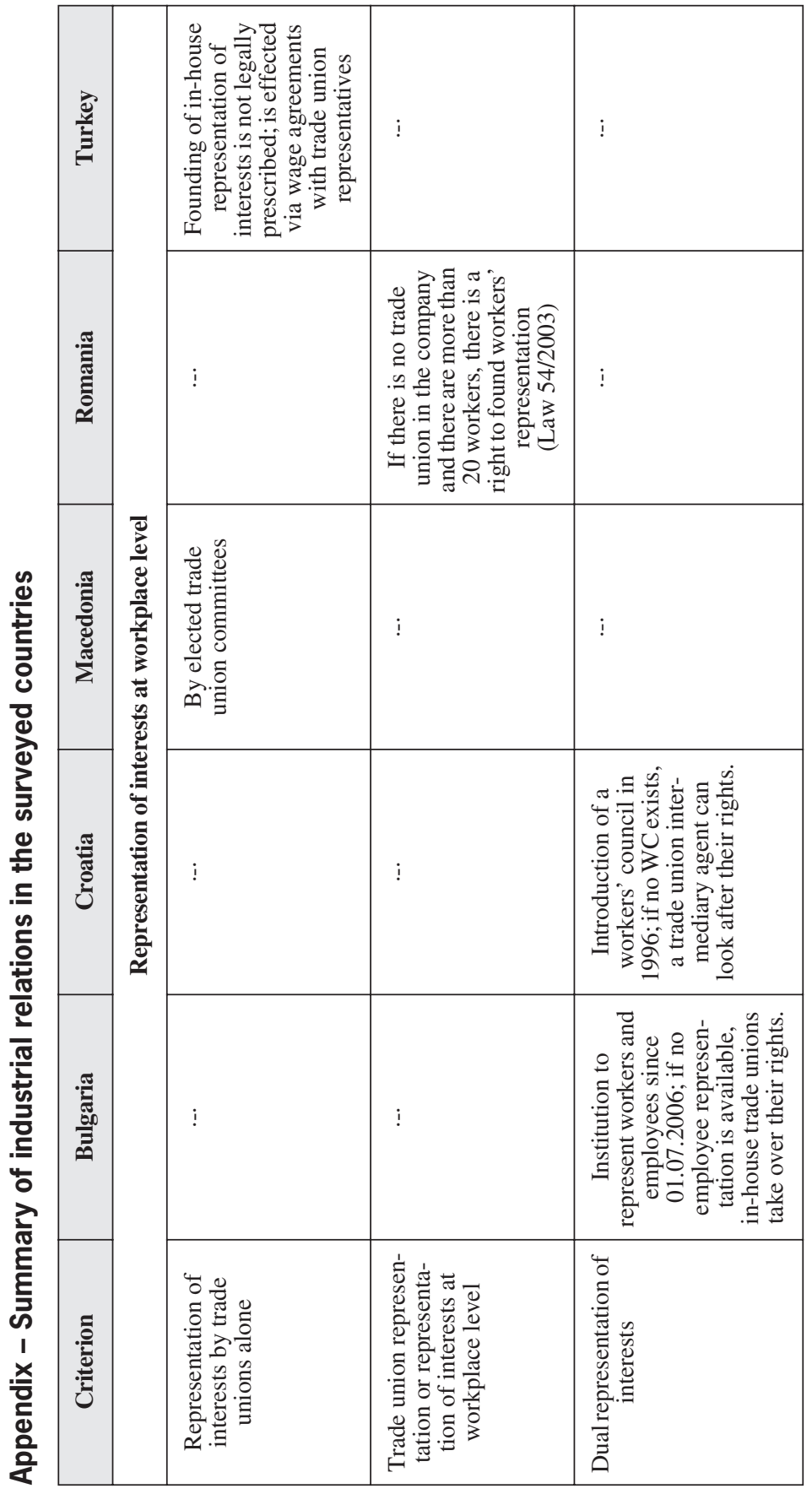




\begin{tabular}{|c|c|c|c|c|c|c|}
\hline $\begin{array}{l}\text { 胥 } \\
\text { 音 }\end{array}$ & 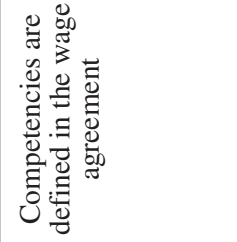 & \multirow{6}{*}{ 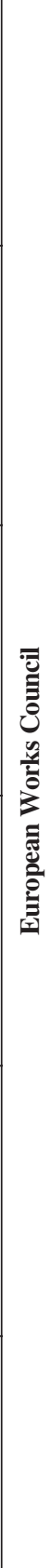 } & $i$ & \multirow{6}{*}{ 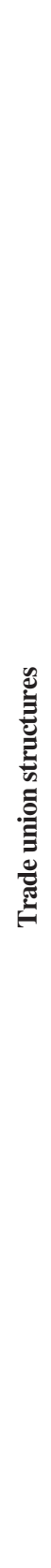 } & 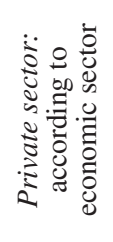 & 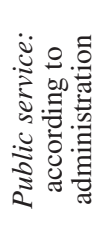 \\
\hline 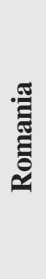 & 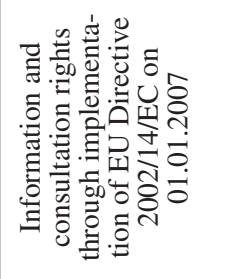 & &  & & 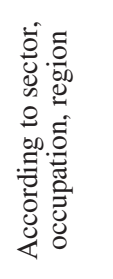 & \\
\hline 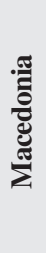 & 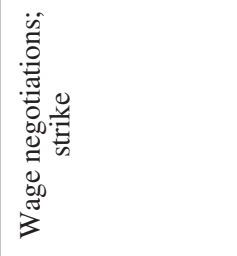 & & $\vdots$ & & 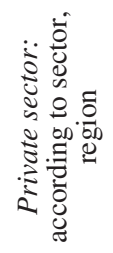 & 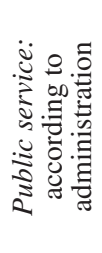 \\
\hline 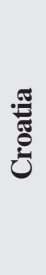 &  & & $\vdots$ & & 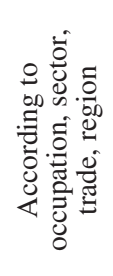 & \\
\hline 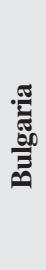 &  & & 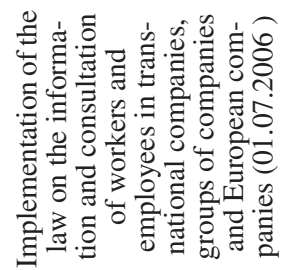 & & 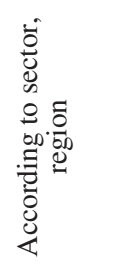 & \\
\hline نَّ &  & & 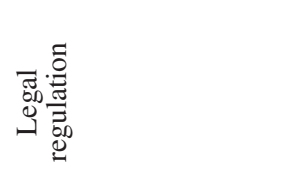 & & 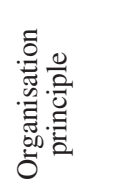 & \\
\hline
\end{tabular}




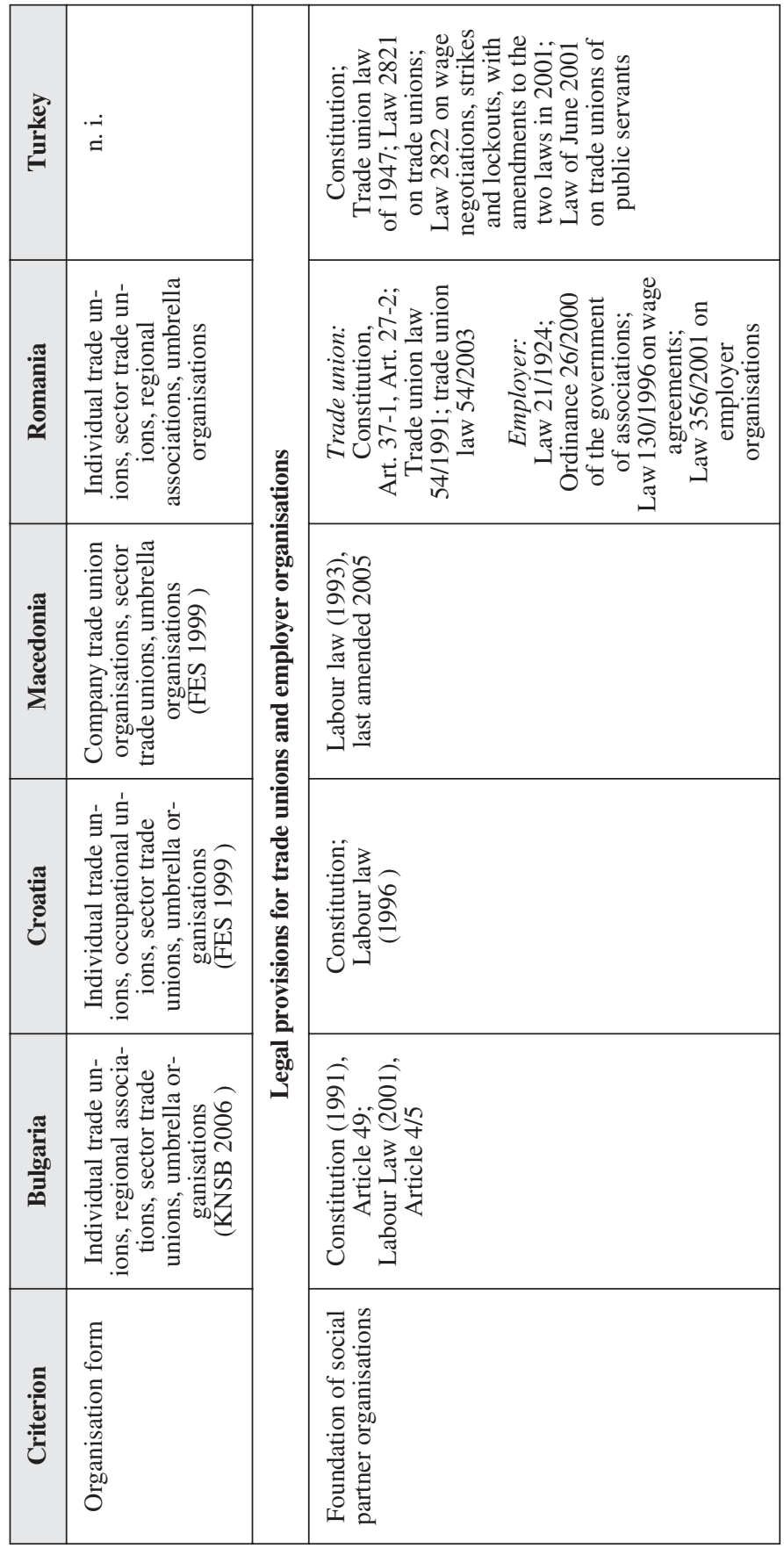




\begin{tabular}{|c|c|c|c|}
\hline 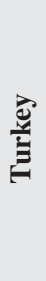 & 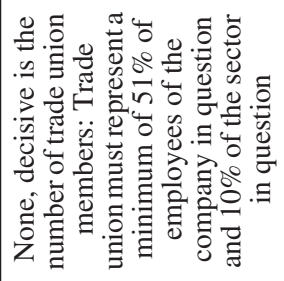 & \multirow{6}{*}{  } & 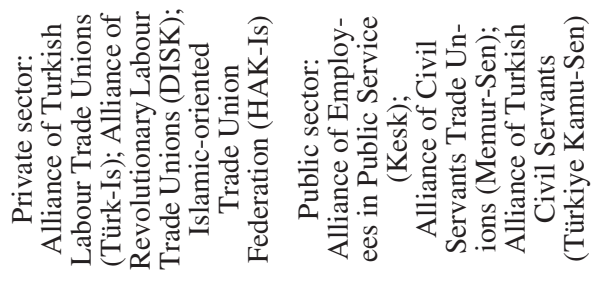 \\
\hline & 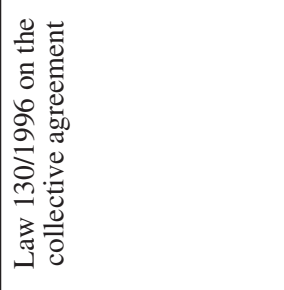 & & 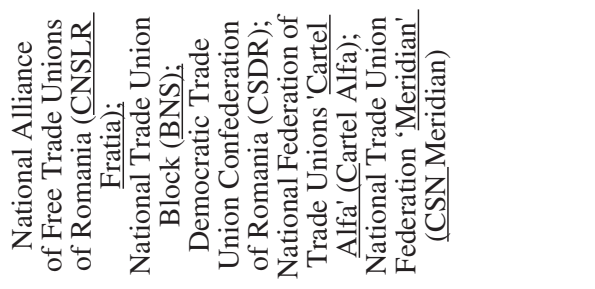 \\
\hline &  & & 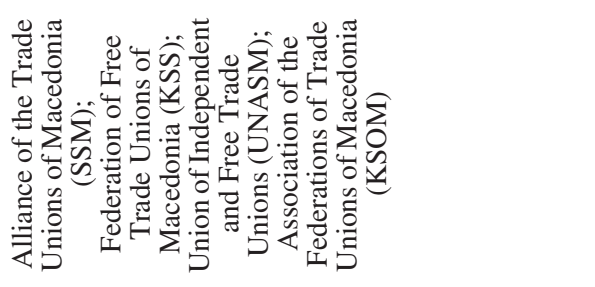 \\
\hline & 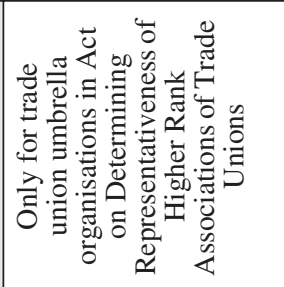 & & 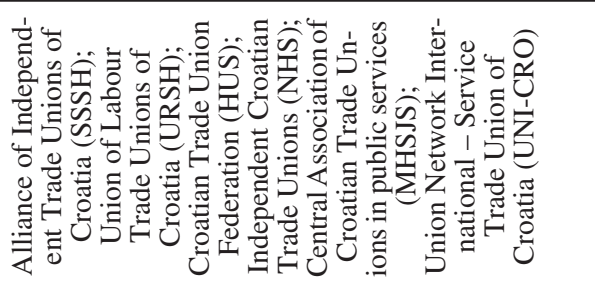 \\
\hline 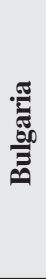 & 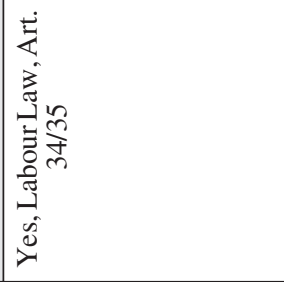 & & 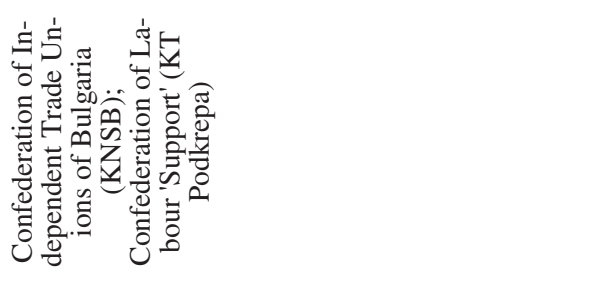 \\
\hline لِّ & 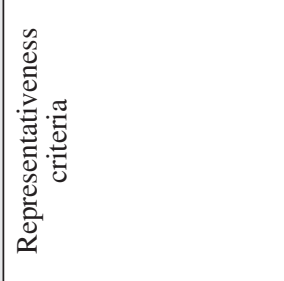 & & 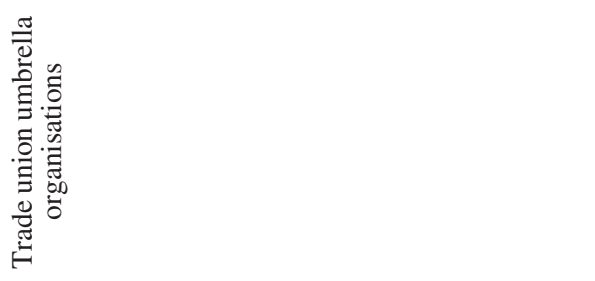 \\
\hline
\end{tabular}




\begin{tabular}{|c|c|c|}
\hline 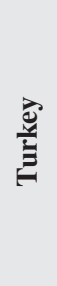 & 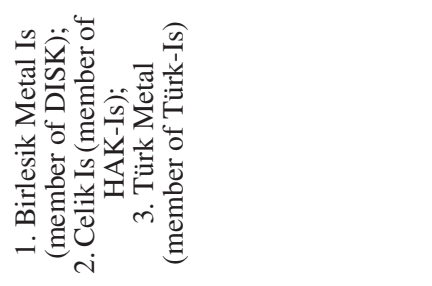 & 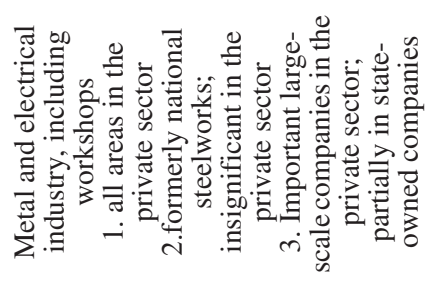 \\
\hline & 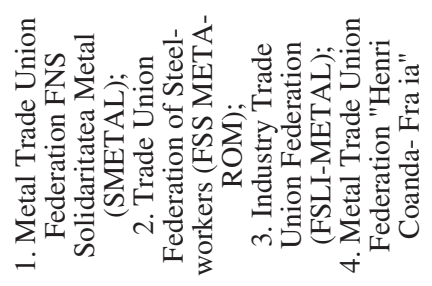 &  \\
\hline 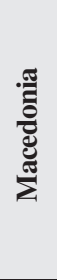 & 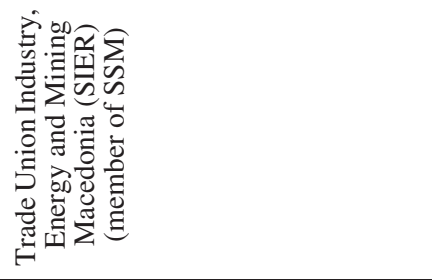 & 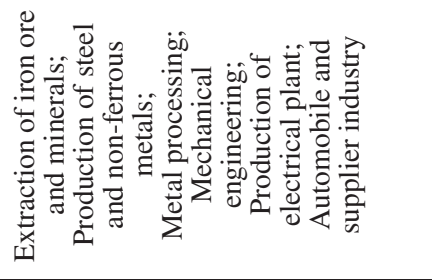 \\
\hline 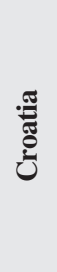 & 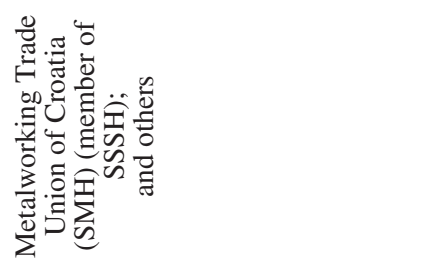 & $\dot{\vec{g}}$ \\
\hline 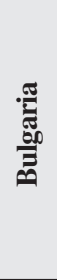 & 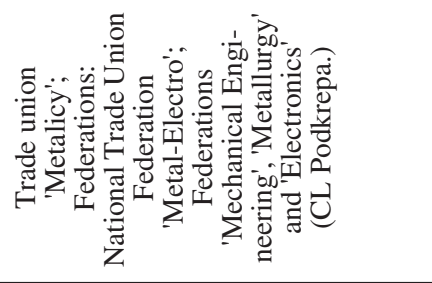 & $\dot{\vec{g}}$ \\
\hline : &  & 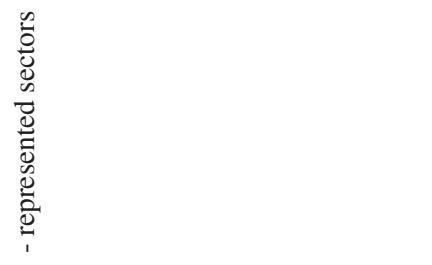 \\
\hline
\end{tabular}




\begin{tabular}{|c|c|}
\hline 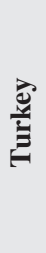 & 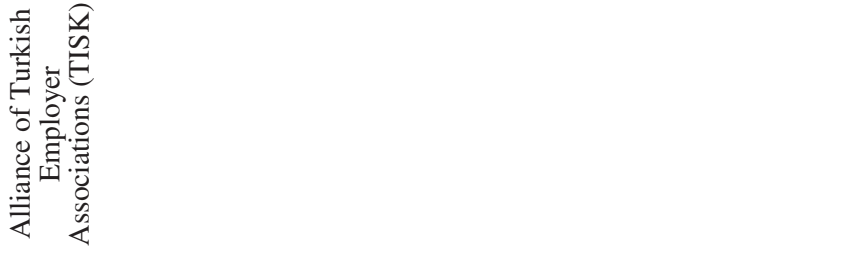 \\
\hline 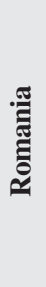 & 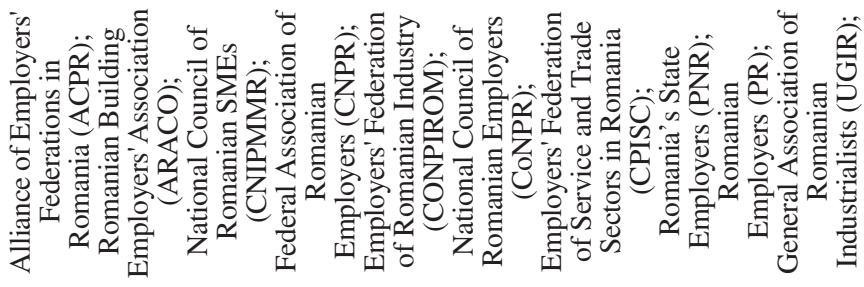 \\
\hline 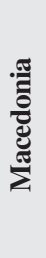 & 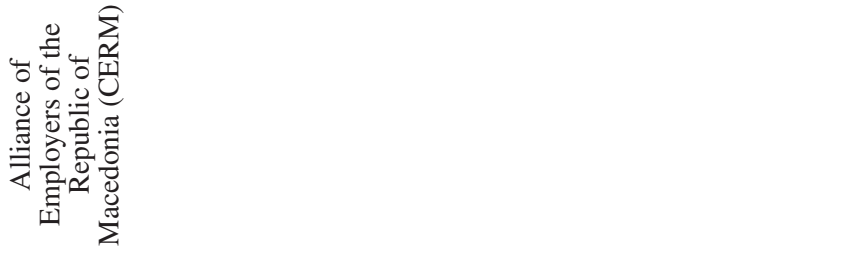 \\
\hline 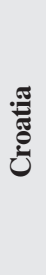 & 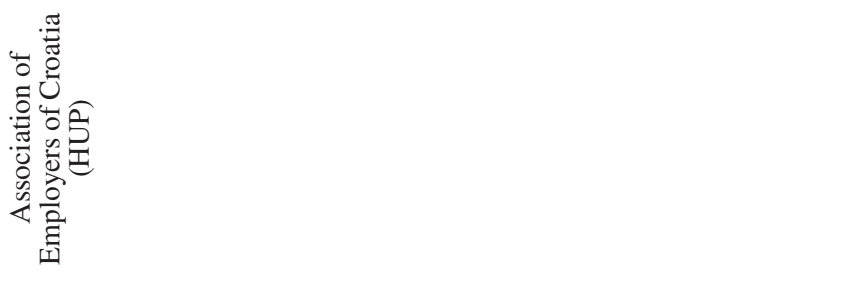 \\
\hline  & 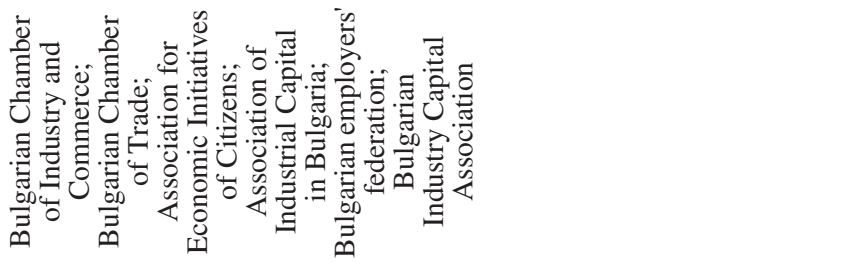 \\
\hline لِّ & 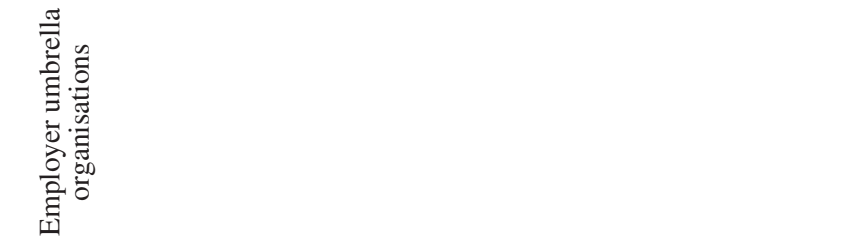 \\
\hline
\end{tabular}




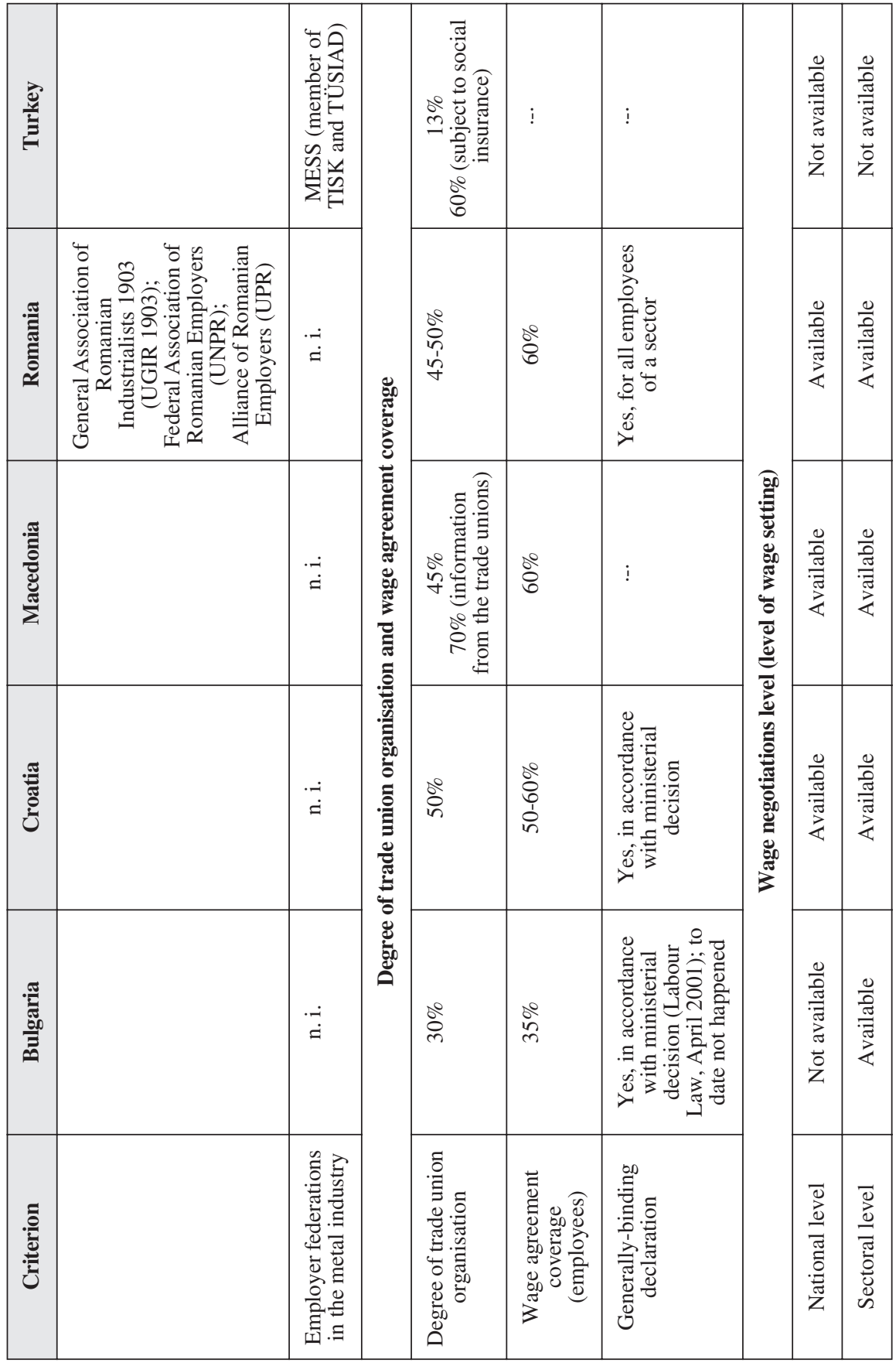




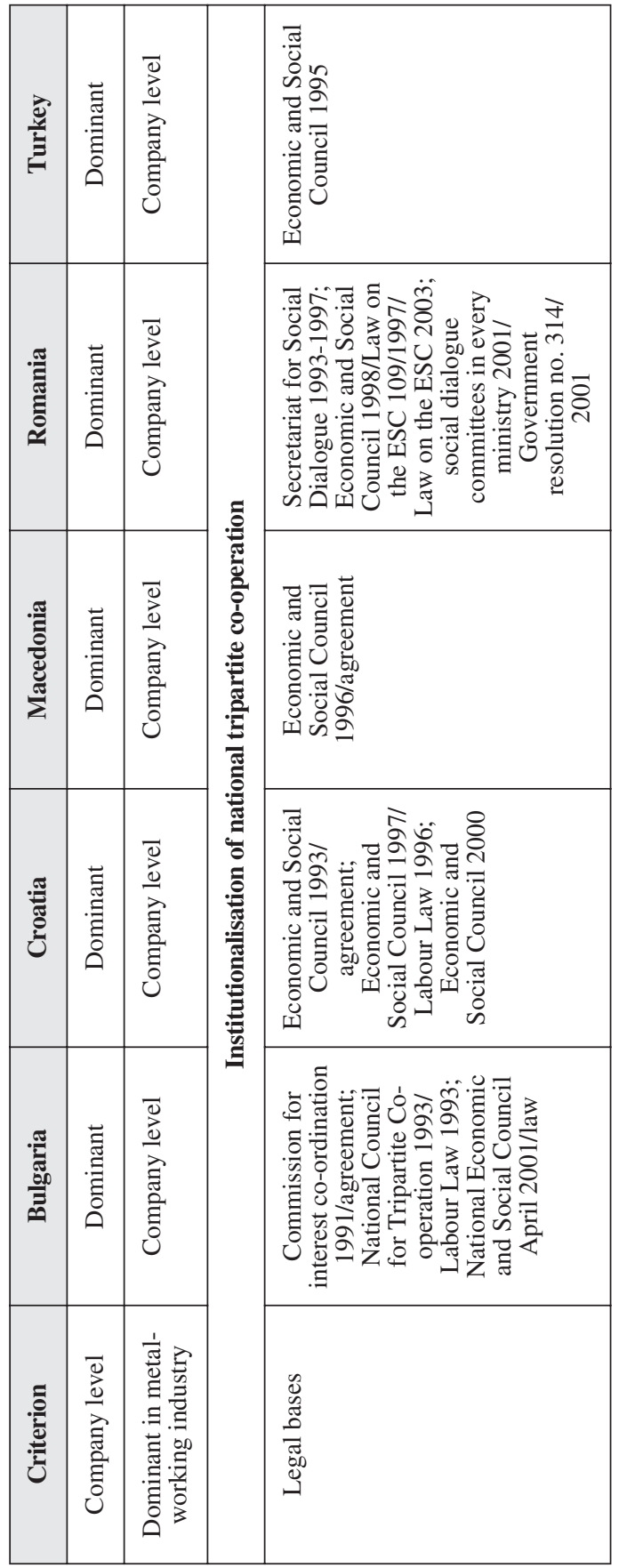




\begin{tabular}{|c|c|c|}
\hline 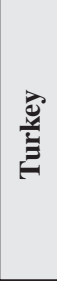 & & 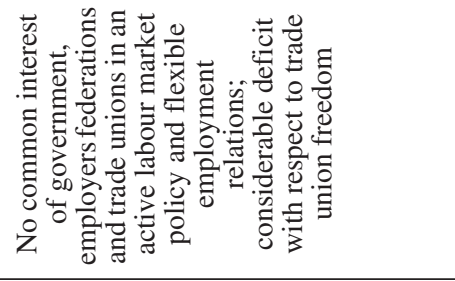 \\
\hline 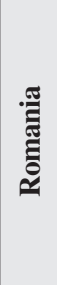 & &  \\
\hline 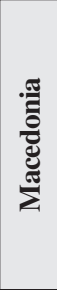 & 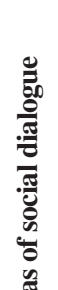 &  \\
\hline 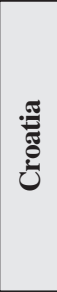 & 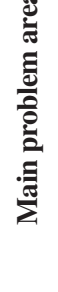 &  \\
\hline 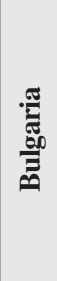 & &  \\
\hline 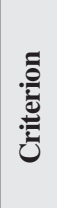 & & 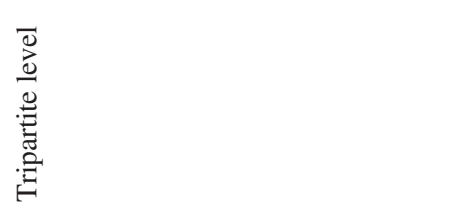 \\
\hline
\end{tabular}




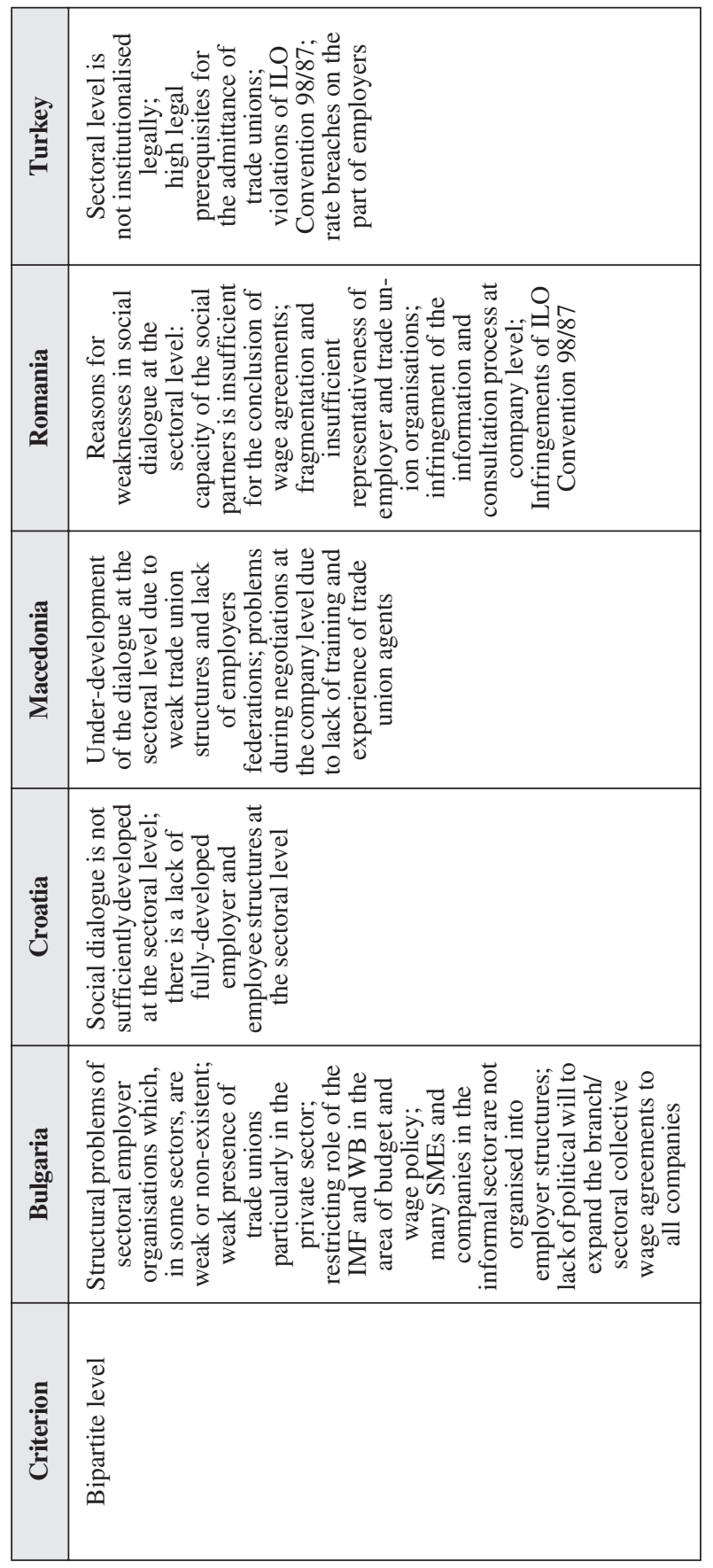

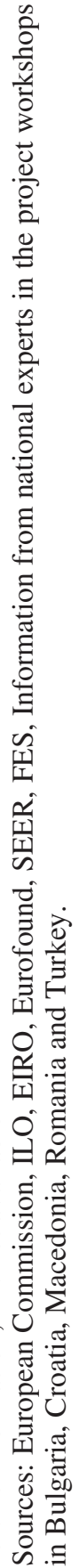

